\title{
Analysis of geographic and taxonomic groups informs conservation of Rhododendron subgenus Vireya (Ericaceae)
}

\author{
M. MacKay ${ }^{1}$, G. Smith², S.E. Gardiner ${ }^{3}$
}

\section{Key words}

botanic gardens

Malesian flora

Red List

Schistanthe

Target 8

threatened species

Vireya

\begin{abstract}
Although Rhododendron subg. Vireya, comprising 400 taxa, is one of the largest plant genera in Southeast Asia, with taxa found throughout the region, it has a significant conservation problem, with conservation status assessments in 2011 and 2015 placing 201 taxa in an IUCN Red List threat category. Plant conservation is driven by the Global Strategy for Plant Conservation, with Target 8 requiring $75 \%$ of threatened plant taxa to be conserved in ex situ collections, by 2020. To date there has been limited analysis of conservation priorities for subg. Vireya, or any consideration of how its geographic characteristics, complex taxonomy, and existing ex situ collections might influence priorities. We analyse the IUCN Red List status of geographic origins and taxonomic sections within Rhododendron subg. Vireya, then determine the representation of those groups in cultivation in New Zealand and selected international collections. Using a set of 'Red List' and 'not in cultivation' factors, our analysis shows that geographic origins New Guinea, Sumatra and Sulawesi, and taxonomic sections Schistanthe: malesia, Schistanthe: euvireya, and Hadranthe (Phaeovireya) should have priority for both in situ and ex situ conservation. Of the 400 taxa, $245(61 \%)$ are in cultivation, and of the 201 Red List taxa, 80 (40\%) are in cultivation. Wild-source material is held for 218 taxa, including 66 Red List taxa. These analyses provide baseline data for development of a conservation strategy for Rhododendron subg. Vireya, and we propose six actions that should be included in that strategy.
\end{abstract}

Published on 20 September 2016

\section{INTRODUCTION}

Rhododendron L. subg. Vireya (C.B.Clarke) H.F.Copel, commonly known as vireya rhododendron, is centred in Southeast Asia, a recognised biodiversity hotspot, and is one of the largest plant groups in the Malesian flora (Van Welzen et al. 2005, Webb \& Ree 2012). The subgenus comprises about 400 taxa (Argent 2015) and, except for 20 taxa (17 from mainland Asia, one from Taiwan, and two from Australia), all taxa are found within the Southeast Asian floristic region (Van Welzen et al. 2005, Argent 2015). Subgenus Vireya has limited geographical overlap with the other eight subgenera of Rhododendron (which are mostly centred on mainland Asia), and there are strong reproductive barriers between Vireya and the other subgenera (Williams et al. 1990, Rouse et al. 1993), indicating that Vireya can be considered independently from the other subgenera for conservation. Two Red List assessments have been conducted for Rhododendron. Gibbs et al. (2011) examined the entire genus, including 338 taxa from subg. Vireya, while Argent (2015) revised the taxonomy of subg. Vireya and as part of that process updated the assessments of 37 taxa and added another 62 assessments for taxa that were either not considered in 2011 or were newly described. A subsequent analysis found that 201 of 400 vireya taxa were either placed in a threat category or listed as Data Deficient and that, of all subgenera, subg. Vireya had the highest priority for ex situ conservation (MacKay \& Gardiner unpubl.).

\footnotetext{
Institute of Agriculture and Environment, Massey University, Private Bag 11-222, Palmerston North 4442, New Zealand;

corresponding author e-mail: m.b.mackay@massey.ac.nz.

2 Former Director (Retired), Pukeiti Rhododendron Garden, New Plymouth, New Zealand.

3 The New Zealand Institute of Plant \& Food Research Limited, Private Bag 11-600, Palmerston North 4442, New Zealand.
}

Subgenus Vireya is a useful case study for conservation because it encompasses a wide range of life forms, (groundcovers, shrubs, trees, epiphytes), which are found in a range of vegetation types (forest, scrub, swamps, grasslands), and in habitats ranging from lowland to montane or alpine zones (Gibbs et al. 2011, Argent 2015). Many horticultural plants have been derived from vireya taxa, and there are hundreds of horticultural cultivars and hybrids (Leslie 2004). Vireyas are subject to a range of threats, mostly associated with deforestation and habitat loss due to agriculture and other production uses (Lasco et al. 2010, Gibbs et al. 2011, Argent 2015), while climate change is a particular threat for alpine species or narrow endemics (Oldfield 2010).

However, conservation planning in Rhododendron is complicated because it is a 'big genus' (Frodin 2004) with complex taxonomy. The sheer size requires a mechanism to determine priorities among many taxa, e.g. the 201 vireya taxa that were Red Listed ${ }^{4}$, or the 60 taxa assessed as Vulnerable. While the Red List categories create an initial hierarchy, other factors such as geographic hotspots, endemism and taxonomic distinctiveness have also been used to shape priorities (Farnsworth et al. 2006, Kozlowski et al. 2012, Castañeda-Álvarez et al. 2015, Cavender et al. 2015). Identifying taxonomic distinctiveness can be problematic in 'big genera' because of their complex taxonomic structures with many subgroups, large numbers of taxonomic queries, frequent hybridisation and active speciation (Crutwell 1988, Frodin 2004, Ennos et al. 2005, Milne et al. 2010, Argent 2015); a comprehensive taxonomy is required to underpin any conservation assessment that considers taxonomic groups.

The taxonomic structure of Rhododendron has been studied many times (Cullen 2005: 11-25), and the current taxonomy

\footnotetext{
${ }^{4}$ Another 514 taxa in other subgenera were also Red Listed, and will be discussed in other papers.
} 
divides the genus into nine subgenera. In this research we focus on subg. Vireya of approximately 400 taxa, in 11 sections and subsections ${ }^{5}$ of 1-119 taxa (Argent 2015); eight subgenera (950 taxa in 61 sections and subsections of 1-97 taxa (Chamberlain et al. 1996)) are not included in this research. DNA sequence analysis supports Argent's (2015) Pseudovireya, Discovireya, and Malayovireya sections, as well as a broad Schistanthe (Euvireya) grouping (Brown et al. 2006a, b, Craven et al. 2008, Goetsch et al. 2011, Fayaz 2012), although support for other sections is less certain. Craven et al. (2011) proposed an alternative structure; however, Argent's sections remain moreor-less intact (although they are at different taxonomic ranks). The molecular work is informative, but the range of taxa used is not yet comprehensive enough to revise the entire taxonomic structure of the subgenus, and Argent's structure remains the most complete framework for a conservation assessment.

Plant conservation practice is directed by the Global Strategy for Plant Conservation (GSPC) and its 16 Targets (Wyse-Jackson \& Kennedy 2009, IUCN 2011, Sharrock 2012, Williams et al. 2012). GSPC Target 2 calls for an assessment of the conservation status of all known plants (as far as possible), to guide conservation action, and thus providing an overview of the 'conservation problem' and indicating initial priorities (Heywood \& Iriondo 2003, Newton \& Oldfield 2008, Kozlowski et al. 2012, Cavender et al. 2015), while ex situ conservation action is further focused by Target 8 , which has the goal of having $75 \%$ of threatened plant taxa in ex situ collections by 2020 (IUCN 2011). Such collections are usually found in botanic gardens, whose role in ex situ conservation is well known (Heywood \& Iriondo 2003, Maunder \& Byers 2005, Oldfield 2009, 2010, Blackmore et al. 2011, Pritchard et al. 2011), and has been recognised for many years (Given 1987). To be effective for ex situ conservation, the collections should meet certain criteria: they should be genetically representative, of known provenance and wild origin, adequately sampled, well documented, verified, and properly labelled (Blackmore et al. 2011, Rae 2011). Unfortunately, many collections do not meet these criteria and therefore have limited use for conservation.

Many collections are 'ad hoc horticultural collections' with few accessions of many taxa, instead of 'structured conservation collections' with appropriate representation (Rae 2011, Cavender et al. 2015). Collections should contain wild-source material; however, this is often limited and documentation is poor (Maunder et al. 2000, 2001a, Kozlowski et al. 2012, Christe et al. 2014). Correct identity is a fundamental principle of ex situ conservation (Leadlay et al. 2006), yet accessions are not always correctly identified (Goodall-Copestake et al. 2005, Paton 2009, Christe et al. 2014). Representation of taxonomic and geographic groups in collections is uneven (Maunder et al. 2001b, Kozlowski et al. 2012, Cavender et al. 2015), and the majority of collections are not in the country of origin (Maunder et al. 2001a, b, Kozlowski et al. 2012). Genetic diversity of most ex situ populations is unknown and is likely to be low (Maunder et al. 2001a, Cavender et al. 2015).

When Red List taxa are in cultivation, the range of taxa present is often limited, whereas most common taxa are in cultivation (Maunder et al. 2001a, b, Oldfield 2010, Kozlowski et al. 2012, Cires et al. 2013, Beech et al. 2015). Furthermore, Red List taxa are often held in three-or-fewer collections, e.g. $46 \%, 63 \%$, and $85 \%$ of rare species were in three-or-fewer collections (Maunder et al. 2001a, b, Rae 2011). In other cases, 29-50\% of Red List taxa were present in only one collection (Maunder et al. 2001a, Powledge 2011, Pritchard et al. 2011, Cires et al.

5 Sections are: Pseudovireya, Discovireya, Malayovireya, Albovireya, Siphonovireya, Hadranthe (previously known as Phaeovireya), and Schistanthe (previously known as Euvireya) which is divided into 5 subsections.
2013). Presence in three-or-fewer collections is effectively 'below the margin of error' and there may be no accessions at all (Lowe 1988, 1989) because: the plant died in the first collection, the identity was wrong in the second collection, and the third collection was going to obtain it but never did. Therefore any taxon recorded in 'three-or-fewer' collections is not secure in cultivation.

Rhododendron subg. Vireya was partially examined in a survey of collections in 2012 (BGCl 2012). This international survey of botanic gardens internationally identified that the largest collections (of the whole genus) world-wide were at Royal Botanic Garden, Edinburgh and Royal Botanic Gardens, Kew. It was also reported that $67 \%$ of 'all taxa' and $53 \%$ of Red List taxa (for the whole genus) were in cultivation, with an average of 5.8 records per taxon for the 48 Endangered and Critically Endangered taxa; however, that study did not consider subg. Vireya separately or examine any geographic or taxonomic groups. Furthermore, the 2012 study did not canvas the breadth of New Zealand collections, accessing only incomplete data from one vireya collection (L. Coxshead pers comm. 2015). New Zealand has a wide diversity of exotic taxa (including Red List taxa) in cultivation (MacKay 1995, 2005, Brockerhoff et al. 2004, Dawson 2010, Arnet et al. 2015); however, there has not previously been any examination specific to Rhododendron and, as there are several New Zealand wild-source collectors of Rhododendron (Argent 2015), there are likely to be other collections that may be applicable for ex situ conservation.

In this study we investigate the Red List status and presence in cultivation of groups of taxa (by geographic origins and taxonomic sections) in Rhododendron subg. Vireya and determine their priority for conservation. The objectives of this work were to:

i. analyse the Red List for Rhododendron subg. Vireya and identify geographic origins and taxonomic sections that should have priority for conservation;

ii. examine the extent to which geographic and taxonomic groups are represented in cultivation, or are not in cultivation;

iii. combine the Red List analysis and the cultivation analysis to identify those groups of taxa that should have priority for ex situ conservation; and

iv. propose conservation action and priorities.

\section{METHODS}

A dataset on Rhododendron subg. Vireya was constructed by creating a base list of taxa (including species, subspecies, and varieties) from Argent (2015), and then adding other data elements. The Red List assessment for each taxon was sourced from Gibbs et al. (2011) and Argent (2015). In those assessments the World Conservation Union (IUCN) assessment criteria (outlined in Gibbs et al. 2011) were used to assign taxa, that have a quantifiable conservation problem, to one of the threat categories (with decreasing degrees of risk): Extinct, Extinct in the Wild, Critically Endangered, Endangered, Vulnerable, and Near Threatened. Those taxa which assessors believe may have a conservation problem, but for which there are insufficient data to quantify the problem, are rated as Data Deficient. High rates of Data Deficiency indicate a paucity of knowledge on the group in question, and therefore a high priority for further research and field work (Newton \& Oldfield 2008, Blackmore et al. 2011, Cires et al. 2013). Those taxa for which there is no evidence of an extinction risk that meets the thresholds in the IUCN Red List system are rated Least Concern.

Data describing taxa in cultivation were obtained from several sources. Firstly, the number of records for each vireya taxon 
on the online Plant Search database at $\mathrm{BGCl}$ was added to the dataset (https://www.bgci.org/plant_search.php. Searched 9-10 Oct. 2015). Secondly, international data were obtained from the online collection databases at Royal Botanic Garden, Edinburgh (Catalogue of the Living collections. http://elmer. rbge.org.uk/bgbase/livcol/bgbaselivcol.php. Searched 9-10 Oct. 2015), Royal Botanic Gardens, Kew (Electronic Plant Information Centre: Living Collections. http://epic.kew.org/ searchepic/searchpage.do. Searched 29 Oct. 2015), and National Botanic Garden Dublin (Alphabetical index to the dicotyledon collections. http://www.botanicgardens.ie/nbg/ dicoidex.htm. Downloaded 11 Oct. 2015). The last named was included because, although it ranks only 12 th for Rhododendron collections world-wide (BGCl 2012), it contains some taxa from the Edinburgh vireya collection (G.Argent pers comm. 2013). Finally, data on New Zealand collections were obtained from prior studies (MacKay 2005, 2013b) and other unpublished data (Smith 2009, unpubl. inventory of the Rhododendron collection at Pukeiti), and from a survey of New Zealand collections (conducted in 2011-2013) for which data were obtained for six private collections and two institutions. Taxa were defined as 'in cultivation' if there was a record from any one data source.

Data were combined into a database, with each record including scientific name, authority, synonyms, taxonomic section (Argent 2015), Red List assessment, geographic origin, presence in collections (New Zealand or internationally), number of accessions on the $\mathrm{BGCl}$ database, and presence of wild-source accessions in any of the collections studied. Plant names were checked using Argent (2015), and only valid taxa were included in the dataset.

Once the dataset was constructed, it was examined in several ways. Firstly, the Red List was analysed, with geographic origins and taxonomic sections (of vireya taxa) ranked according to each of four Red List factors (number of taxa Red Listed, percentage of taxa Red Listed, number of Red List taxa rated Data Deficient, percentage of Red List taxa rated Data Deficient). A score was assigned to each rank. Each geographic origin or taxonomic section had four ranking scores (one for each Red List factor) and those scores were summed to generate a Red List score, e.g. the score for New Guinea is $11+4+11+9=35$, and for Schistanthe: malesia is $9+9+9+6=33$. Origins and sections with the highest scores were assigned highest priority. Geographic origins in Southeast Asia were assigned to islands, not countries; for example New Guinea and Borneo were the assigned origins, not the countries within those islands. Secondly, data on taxa in cultivation were collated to show the extent to which geographic and taxonomic groups are in cultivation. Thirdly, a set of 'not in cultivation' factors were examined, as the absence from cultivation also generates a high priority for ex situ conservation. Using the same process as the Red List analysis (described above), geographic origins and taxonomic sections were ranked for four 'not in cultivation' factors, a score assigned to each rank, and a 'not in cultivation' score was generated for by summing the ranking scores. For example, the score for New Guinea is $10+9+10+8=37$, and for Hadranthe is $9+9+8+7=33$. The final aspect of data processing was generation of a Total Score (Red List score + 'not in cultivation' score), thereby identifying those groups of taxa that ranked highly in the Red List assessment but which also had low frequency in cultivation. These groups will have highest priority for ex situ conservation.

\section{RESULTS AND DISCUSSION}

\section{Red List status for subg. Vireya}

When combined, the Red List assessments of Gibbs et al. (2011) and Argent (2015) examined 400 vireya taxa, of which
Table 1 Rhododendron subg. Vireya (Argent 2015): number of taxa in Red List categories*

\begin{tabular}{lc}
\hline Threat category & No. of taxa \\
\hline Extinct & 2 \\
Extinct in the Wild & 0 \\
Critically Endangered & 12 \\
Endangered & 12 \\
Vulnerable & 60 \\
Near Threatened & 2 \\
Total in threat categories & 88 \\
Data Deficient & 113 \\
Total Red Listed & 201 \\
Least Concern & 199 \\
Total Assessed & 400
\end{tabular}

Gibbs et al. (2011) assessed 338 taxa. Argent (2015) assessed another 62 and updated 37 others.

201 (50 \%) were Red Listed (Table 1). The percentage Red Listed is similar to or slightly higher than recent assessments for Quercus (53\%), Acer (44\%), and Betulaceae (43\%) (Oldfield \& Eastwood 2007, Gibbs \& Chen 2009, Shaw et al. 2014). Magnoliaceae (Rivers et al. 2016) had a higher percentage of taxa Red Listed (85 \%), from a group of 304 taxa. The greatest number of vireya Red List taxa occur in the Vulnerable (60 taxa) and Data Deficient (113 taxa) categories; indeed, the percentage of Data Deficient ${ }^{6}$ ratings for vireya (56\%) is high compared with those for Acer (25\%), Quercus (30\%), or Magnoliaceae (38 \%) (Oldfield \& Eastwood 2007, Gibbs \& Chen

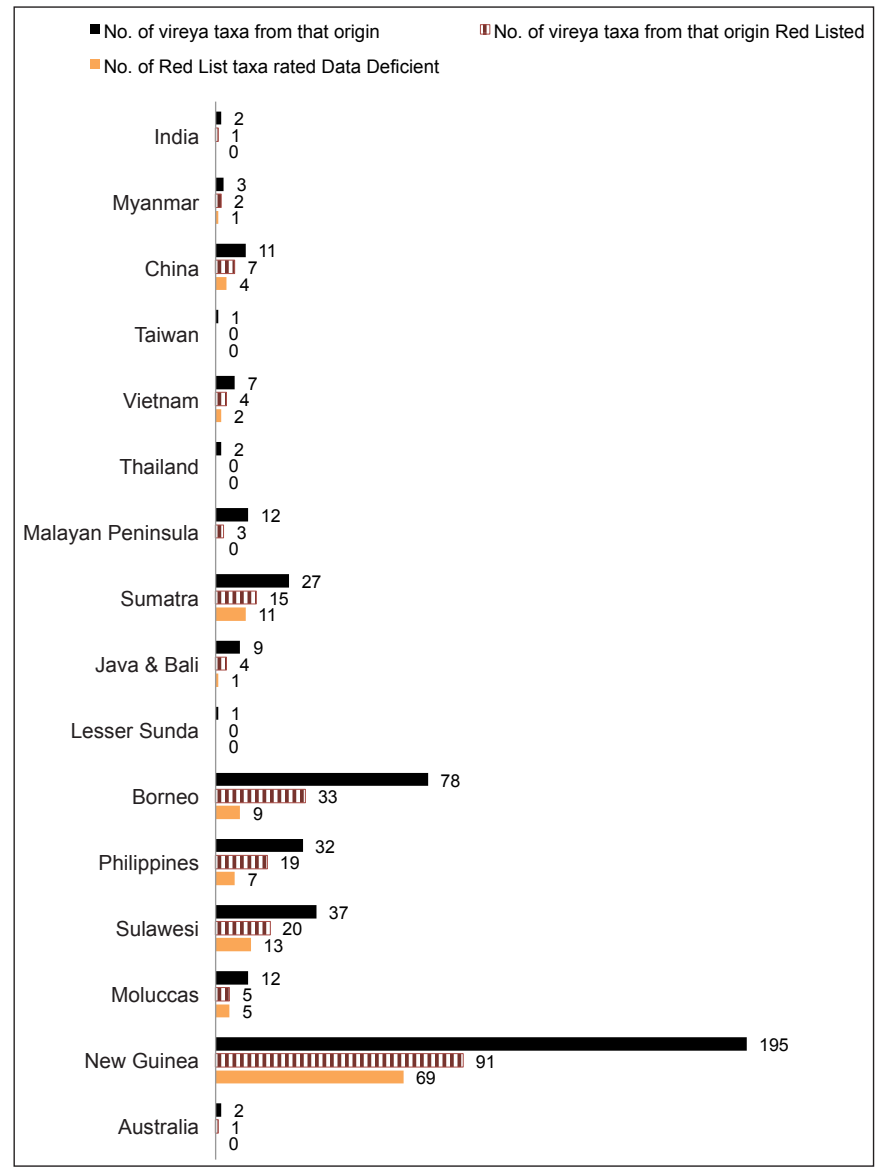

Fig. 1 Red List analysis for geographic origins of Rhododendron subg. Vireya (Argent 2015): number of taxa, number of Red List taxa, and number of Red List taxa rated Data Deficient, from each origin. (Total no. of taxa = 400; however, top bars will not sum to 400 as some taxa have more than one origin.)

${ }^{6}$ Number of Data Deficient taxa / (No. of taxa in Threat categories + Number of Data Deficient taxa) $\times 100$. 
Table 2 Geographic origins of Rhododendron subg. Vireya (Argent 2015) ranked according to four Red List factors.

\begin{tabular}{|c|c|c|c|c|c|c|c|c|}
\hline \multirow[t]{2}{*}{ Ranking score } & \multicolumn{2}{|c|}{ No. of taxa Red Listed } & \multicolumn{2}{|c|}{ Percentage of taxa Red Listed } & \multicolumn{2}{|l|}{$\begin{array}{l}\text { No. of Red List taxa } \\
\text { rated Data Deficient }\end{array}$} & \multicolumn{2}{|c|}{$\begin{array}{l}\text { Percentage of Red List taxa } \\
\text { rated Data Deficient }\end{array}$} \\
\hline & Origin & No. & Origin & $\%$ & Origin & No. & Origin & $\%$ \\
\hline 11 & New Guinea & 91 & Myanmar & 67 & New Guinea & 69 & Moluccas & 100 \\
\hline 10 & Borneo & 33 & China & 64 & Sulawesi & 13 & Sumatra & 73 \\
\hline 9 & Sulawesi & 20 & Philippines & 59 & Sumatra & 11 & New Guinea & 69 \\
\hline 8 & Philippines & 19 & Vietnam & 57 & Borneo & 09 & Sulawesi & 65 \\
\hline 7 & Sumatra & 15 & Sumatra & 56 & Philippines & 07 & China & 57 \\
\hline 6 & China & 07 & Sulawesi & 54 & Moluccas & 05 & $\begin{array}{l}\text { Myanmar } \\
\text { Vietnam }\end{array}$ & $\begin{array}{l}50 \\
50\end{array}$ \\
\hline 5 & Moluccas & 05 & $\begin{array}{l}\text { Australia } \\
\text { India }\end{array}$ & $\begin{array}{l}50 \\
50\end{array}$ & China & 04 & Philippines & 37 \\
\hline 4 & $\begin{array}{l}\text { Java \& Bali } \\
\text { Vietnam }\end{array}$ & $\begin{array}{l}04 \\
04\end{array}$ & New Guinea & 47 & Vietnam & 02 & Borneo & 27 \\
\hline 3 & Malayan Peninsula & 03 & Java \& Bali & 44 & $\begin{array}{l}\text { Myanmar } \\
\text { Java \& Bali }\end{array}$ & $\begin{array}{l}01 \\
01\end{array}$ & Java \& Bali & 25 \\
\hline 2 & Myanmar & 02 & $\begin{array}{l}\text { Borneo } \\
\text { Moluccas }\end{array}$ & $\begin{array}{l}42 \\
42\end{array}$ & & & & \\
\hline 1 & $\begin{array}{l}\text { Australia } \\
\text { India }\end{array}$ & $\begin{array}{l}01 \\
01\end{array}$ & Malayan Peninsula & 25 & & & & \\
\hline 0 : nil taxa for the factor & $\begin{array}{l}\text { Lesser Sunda } \\
\text { Thailand } \\
\text { Taiwan }\end{array}$ & & $\begin{array}{l}\text { Lesser Sunda } \\
\text { Thailand } \\
\text { Taiwan }\end{array}$ & & $\begin{array}{l}\text { Australia } \\
\text { India } \\
\text { Lesser Sunda } \\
\text { Malayan Peninsula } \\
\text { Thailand } \\
\text { Taiwan }\end{array}$ & & $\begin{array}{l}\text { Australia } \\
\text { India } \\
\text { Lesser Sunda } \\
\text { Malayan Peninsula } \\
\text { Thailand } \\
\text { Taiwan }\end{array}$ & \\
\hline
\end{tabular}

2009, Rivers et al. 2016), although Betulaceae was more poorly placed with $80 \%$ of Red List taxa rated Data Deficient (Shaw et al. 2014). High percentages of Data Deficiency indicate a knowledge and research issue which may hinder development of conservation plans (Newton \& Oldfield 2008, Blackmore et al. 2011, Cires et al. 2013).

\section{Red List analysis for geographic origins of subg. Vireya}

Among the geographic origins of vireya taxa, New Guinea (91 taxa) and Borneo (33) have the greatest number of Red List taxa, while New Guinea (69) and Sulawesi (13) have the greatest number of Data Deficient taxa (Fig. 1, which displays an eastwards progression of geographic origins from top to bottom). Myanmar and China have the highest percentage of taxa Red Listed (Table 2), although there are only 12 taxa from those origins. The highest percentages of Red List taxa rated Data Deficient originate from the Moluccas and New Guinea (Table 2). The Red List score shows that New Guinea, Sumatra, and Sulawesi are priority geographic origins for conservation, followed by the Philippines, China and the Moluccas (Table 3). New Guinea dominates because of the number of taxa

Table 3 Geographic origins of Rhododendron subg. Vireya (Argent 2015) ranked according to Red List score.

\begin{tabular}{|c|c|}
\hline Origin & $\begin{array}{l}\text { Red List score }=\text { sum of ranking scores for four } \\
\text { Red List factors (Table 2). Maximum score }=44\end{array}$ \\
\hline New Guinea & 35 \\
\hline Sumatra & 33 \\
\hline Sulawesi & 33 \\
\hline Philippines & 29 \\
\hline China & 28 \\
\hline Moluccas & 24 \\
\hline Borneo & 24 \\
\hline Vietnam & 22 \\
\hline Myanmar & 22 \\
\hline Java \& Bali & 13 \\
\hline Australia & 6 \\
\hline India & 6 \\
\hline Malayan Peninsula & 4 \\
\hline Lesser Sunda & 0 \\
\hline Thailand & 0 \\
\hline Taiwan & 0 \\
\hline
\end{tabular}

and the number of taxa rated Data Deficient, while Sumatra and Sulawesi rank highly because of Data Deficiency. Borneo, which has the second highest number of Red List taxa, is sixth in the Red List score ranking, because of the relatively low percentages of taxa Red Listed and taxa rated Data Deficient.

Red List analysis for taxonomic sections of subg. Vireya The greatest numbers of Red List taxa are in taxonomic sections Schistanthe: euvireya (59 taxa) and Schistanthe: malesia (34 taxa); those two sections also had the greatest numbers

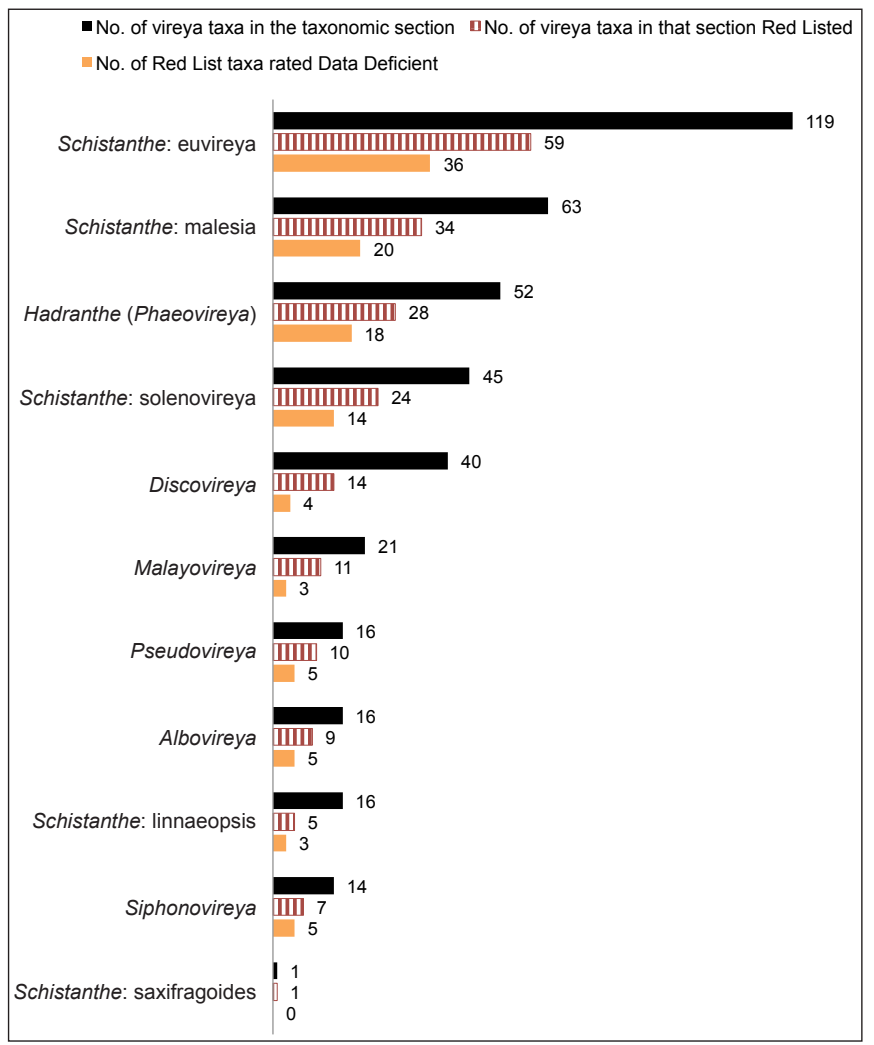

Fig. 2 Red List analysis for taxonomic sections of Rhododendron subg. Vireya (Argent 2015): number of taxa, number of Red List taxa, and number of Red List taxa rated Data Deficient, in each section. 
Table 4 Taxonomic sections of Rhododendron subg. Vireya (Argent 2015) ranked according to four Red List factors.

\begin{tabular}{|c|c|c|c|c|c|c|c|c|}
\hline \multirow[t]{2}{*}{ Ranking score } & \multicolumn{2}{|l|}{ No. of taxa Red Listed } & \multicolumn{2}{|l|}{ Percentage of taxa Red Listed } & \multicolumn{2}{|l|}{$\begin{array}{l}\text { No. of Red List taxa } \\
\text { rated Data Deficient }\end{array}$} & \multicolumn{2}{|l|}{$\begin{array}{l}\text { Percentage of Red List taxa } \\
\text { rated Data Deficient }\end{array}$} \\
\hline & Section & No. & Section & $\%$ & Section & No. & Section & $\%$ \\
\hline 10 & Schistanthe: euvireya & 59 & Pseudovireya & 63 & Schistanthe: euvireya & 36 & Siphonovireya & 71 \\
\hline 9 & Schistanthe: malesia & 34 & Schistanthe: malesia & 57 & Schistanthe: malesia & 20 & Hadranthe (Phaeovireya) & 64 \\
\hline 8 & Hadranthe (Phaeovireya) & 28 & Albovireya & 56 & Hadranthe (Phaeovireya) & 18 & Schistanthe: euvireya & 61 \\
\hline 7 & Schistanthe: solenovireya & 24 & Hadranthe (Phaeovireya) & 54 & Schistanthe: solenovireya & 14 & Schistanthe: linnaeopsis & 60 \\
\hline 6 & Discovireya & 14 & $\begin{array}{l}\text { Malayovireya } \\
\text { Schistanthe: solenovireya }\end{array}$ & $\begin{array}{l}53 \\
53\end{array}$ & $\begin{array}{l}\text { Albovireya } \\
\text { Pseudovireya } \\
\text { Siphonovireya }\end{array}$ & $\begin{array}{l}05 \\
05 \\
05\end{array}$ & Schistanthe: malesia & 59 \\
\hline 5 & Malayovireya & 11 & $\begin{array}{l}\text { Siphonovireya } \\
\text { Schistanthe: euvireya }\end{array}$ & $\begin{array}{l}50 \\
50\end{array}$ & Discovireya & 04 & Schistanthe: solenovireya & 58 \\
\hline 4 & Pseudovireya & 10 & Discovireya & 35 & $\begin{array}{l}\text { Schistanthe: linnaeopsis } \\
\text { Malayovireya }\end{array}$ & $\begin{array}{l}03 \\
03\end{array}$ & Albovireya & 55 \\
\hline 3 & Albovireya & 09 & Schistanthe: linnaeopsis & 31 & & & Pseudovireya & 50 \\
\hline 2 & Siphonovireya & 07 & & & & & Discovireya & 29 \\
\hline $\begin{array}{l}0 \text { : nil taxa for the } \\
\text { factor }\end{array}$ & Schistanthe: saxifragoides & & Schistanthe: saxifragoides & & Schistanthe: saxifragoides & & Schistanthe: saxifragoides & \\
\hline
\end{tabular}

Table 5 Taxonomic sections of Rhododendron subg. Vireya (Argent 2015) ranked according to Red List score.

\begin{tabular}{ll}
\hline Taxonomic section & Red List score $=$ sum of ranking scores for four \\
& Red List factors $($ Table 4$)$. Maximum score $=40$
\end{tabular}

Schistanthe: malesia 33

Schistanthe: euvireya 33

Hadranthe (Phaeovireya) 32

Schistanthe: solenovireya $\quad 25$

Siphonovireya 23

Pseudovireya 23

Albovireya $\quad 21$

Discovireya $\quad 17$

Malayovireya $\quad 16$

Schistanthe: linnaeopsis $\quad 15$

Schistanthe: saxifragoides 0

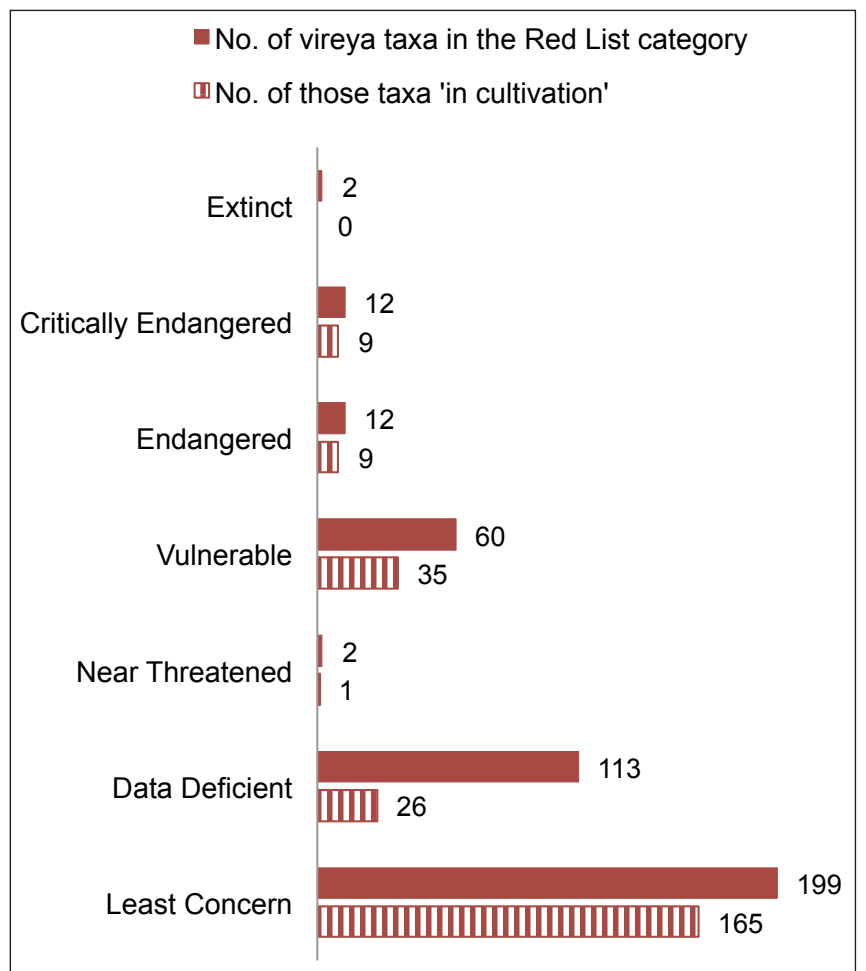

Fig. 3 Taxa in cultivation for Red List categories of Rhododendron subg Vireya (Argent 2015): number of taxa from each category 'in cultivation' in 2015 (MacKay \& Gardiner unpubl.). of Data Deficient taxa (Fig. 2, Table 4). Ranking of taxonomic sections by percentage of taxa Red Listed (Table 4), reveals that Pseudovireya and Schistanthe: malesia have the highest percentages, while Siphonovireya and Hadranthe (Phaeovireya) have the highest percentages of taxa rated Data Deficient. The Red List score shows that Schistanthe: malesia, Schistanthe: euvireya (equal first rank), and Hadranthe (Phaeovireya) are priority taxonomic groups for conservation (Table 5).

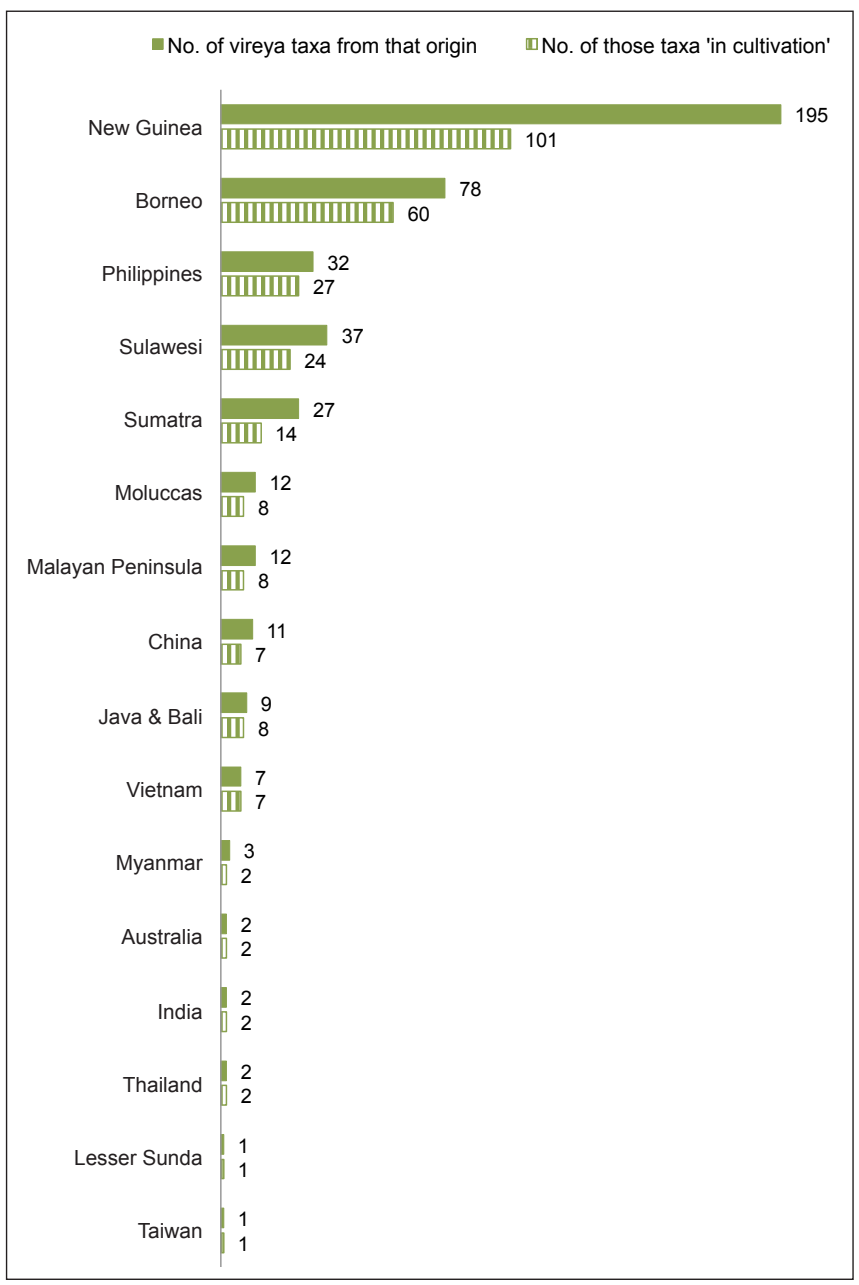

Fig. 4 Taxa in cultivation for geographic origins of Rhododendron subg. Vireya (Argent 2015): number of taxa from each geographic origin 'in cultivation' in 2015. 
Table 6 Geographic origins of Rhododendron subg. Vireya (Argent 2015): ranked according to the average number of records per taxon at Botanic Gardens Conservation International (BGCl) for Red List taxa from each origin.

\begin{tabular}{lcc}
\hline Origin & $\begin{array}{c}\text { Average number of records } \\
\text { per Red List taxon at BGCl }\end{array}$ & $\begin{array}{c}\text { No. of Red List taxa } \\
\text { from that origin }\end{array}$ \\
\hline Moluccas & 0 & 5 \\
Sumatra & 0.3 & 15 \\
New Guinea & 0.6 & 91 \\
Sulawesi & 0.7 & 20 \\
Myanmar & 1.0 & 2 \\
Malayan Peninsula & 1.0 & 3 \\
Borneo & 1.3 & 33 \\
China & 1.4 & 7 \\
Java \& Bali & 1.8 & 4 \\
Philippines & 1.8 & 19 \\
Vietnam & 2.0 & 4 \\
India & 5.0 & 1 \\
Australia & 10 & 1 \\
\hline
\end{tabular}

\section{Subg. Vireya 'in cultivation'}

MacKay \& Gardiner (unpubl.) found that of the 400 Vireya taxa examined by Argent (2015) and Gibbs et al. (2011), 245 (61 \%) were 'in cultivation' (using the same definition as in this study), including 80 of the 201 Red List taxa (40 \%) (Fig. 3). When Red List taxa were considered by category, they found that $61 \%$ of taxa in threat categories were in cultivation, but only $23 \%$ of Data Deficient taxa. Vireya taxa were also poorly placed by the $\mathrm{BGCl}$ database, with an average of only 2.1 records per taxon for 'all vireya taxa' and 0.9 for Red List taxa (MacKay \& Gardiner unpubl.), well below the 'three-or-fewer' indicator of risk. When taxa in cultivation are considered by geographic origin (Fig. 4), New Guinea is the origin of the greatest number of taxa in cultivation (101 taxa), followed by Borneo (60). Six origins have all their taxa in cultivation (15 taxa in total), and another five origins (Java \& Bali, Philippines, Borneo, Moluccas, Malayan Peninsula) have more than $75 \%$ of their taxa in cultiva-

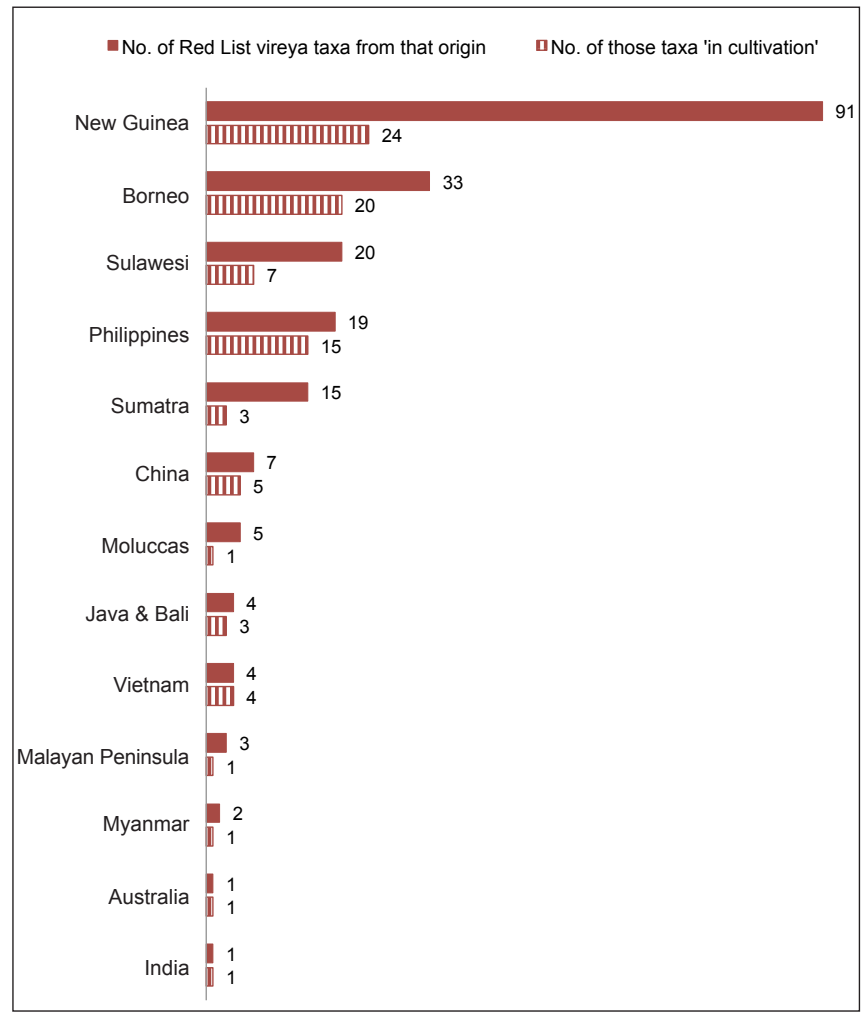

Fig. 5 Red List taxa in cultivation for geographic origins of Rhododendron subg. Vireya (Argent 2015): number of Red List taxa from each geographic origin 'in cultivation' in 2015.
Table 7 Taxonomic sections of Rhododendron subg. Vireya (Argent 2015): ranked according to the average number of records per taxon at $\mathrm{BGCl}$ for Red List taxa in each section.

\begin{tabular}{lcc}
\hline Taxonomic section & $\begin{array}{c}\text { Average number of records } \\
\text { per Red List taxon at BGCl }\end{array}$ & $\begin{array}{c}\text { No. of Red List } \\
\text { taxa in the section }\end{array}$ \\
\hline Siphonovireya & 0.1 & 7 \\
Hadranthe (Phaeovireya) & 0.3 & 28 \\
Schistanthe: linnaeopsis & 0.4 & 5 \\
Discovireya & 0.5 & 14 \\
Schistanthe: malesia & 0.8 & 34 \\
Albovireya & 0.9 & 9 \\
Schistanthe: solenovireya & 1.0 & 24 \\
Malayovireya & 1.2 & 11 \\
Schistanthe: euvireya & 1.2 & 59 \\
Pseudovireya & 1.7 & 10 \\
\hline
\end{tabular}

tion. The geographic origin with the greatest number of Red List taxa in cultivation (Fig. 5) is New Guinea (24 taxa), followed by Borneo (20). Three origins (India, Australia, Vietnam, six taxa in total) have $100 \%$ of their Red List taxa in cultivation, and the Philippines (79 \%) and Java \& Bali $(75 \%)$ have more than $75 \%$ of Red List taxa in cultivation; however, these areas represent only $14 \%$ of the Red List taxa, and the origins with the greatest number of Red List taxa do not reach the $75 \%$ Target (e.g., only $26 \%$ of Red List taxa from New Guinea are in cultivation). Furthermore, the average number of records on the BGCl database is poor: only India (one taxon) and Australia (one taxon) have more than three records per Red List taxon (Table 6). Of the other origins, the Moluccas ( 0 records per taxon), Sumatra (0.3), New Guinea (0.6), and Sulawesi (0.7) have an average of less than one $\mathrm{BGCl}$ record per Red List taxon.

With respect to taxonomic sections, the largest sections (Schistanthe: euvireya, Schistanthe: malesia) have the greatest number of taxa in cultivation (Fig. 6). Only Schistanthe: saxifragoides

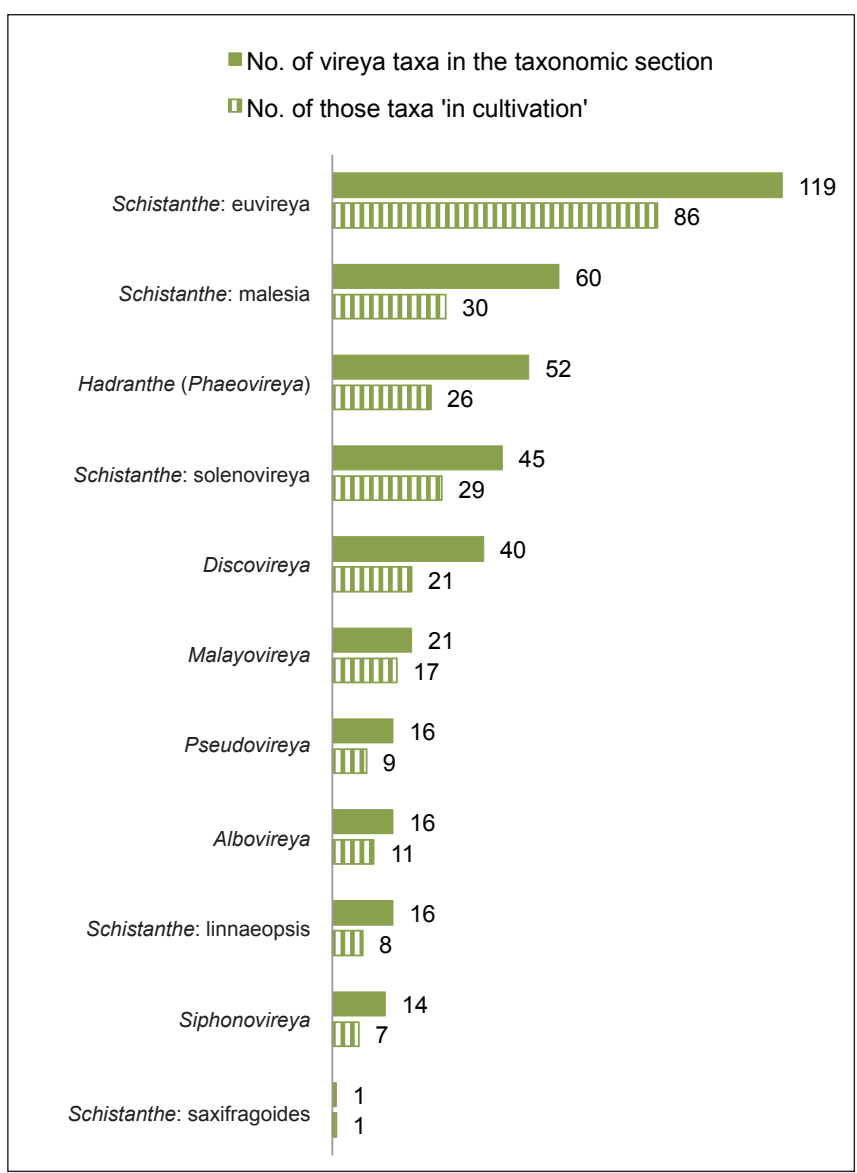

Fig. 6 Taxa in cultivation for taxonomic sections of Rhododendron subg. Vireya (Argent 2015): number of taxa 'in cultivation' in 2015. 


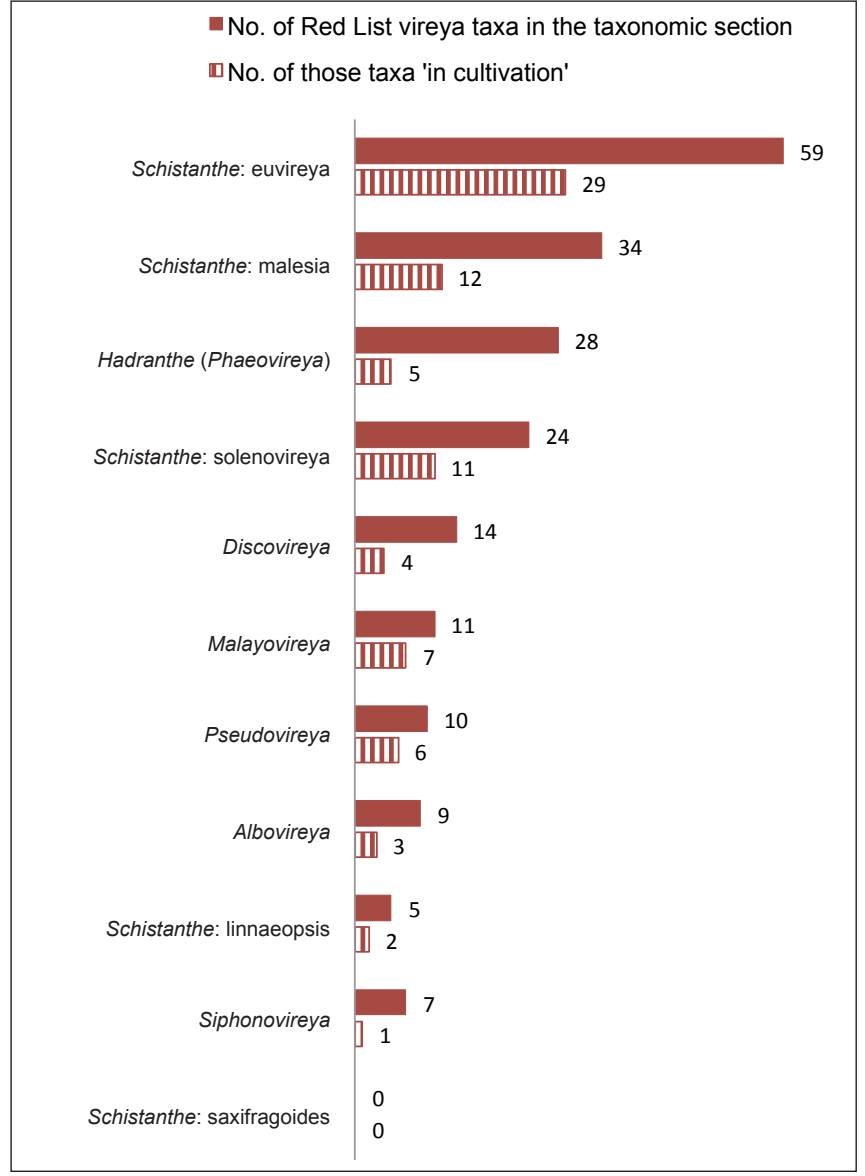

Fig. 7 Red List taxa in cultivation for taxonomic sections of Rhododendron subg. Vireya (Argent 2015): number of Red List taxa 'in cultivation' in 2015.
(100\%) and Malayovireya ( $81 \%$ ) have more than $75 \%$ of taxa in cultivation. The greatest number of Red List taxa in cultivation (Fig. 7) are from Schistanthe: euvireya (29 taxa), followed by Schistanthe: malesia (12 taxa). No taxonomic section has more than $75 \%$ of its Red List taxa in cultivation - the figures range from $64 \%$ for Malayovireya to $14 \%$ for Siphonovireya. Of the sections prioritised in the Red List analysis, Schistanthe: euvireya is in the best position (49\% of Red List taxa in cultivation), while Schistanthe: malesia (35\%) and Hadranthe (18\%) are poorly placed. All taxonomic sections are poorly placed with respect to average number of records per Red List taxon on the BGCl database (Table 7). Siphonovireya is in the worst position, with an average of 0.1 records per Red List taxon: five other sections have an average of less than 1.0, and three sections have an average of between 1.2 and 1.7 .

Table 9 Geographic origins of Rhododendron subg. Vireya (Argent 2015) ranked according to 'not in cultivation' score.

\begin{tabular}{lc}
\hline Origin & $\begin{array}{c}\text { 'Not in cultivation' score }=\text { sum of ranking scores for four } \\
\text { 'not in cultivation' factors (Table 8). Maximum score }=40\end{array}$ \\
\hline New Guinea & 37 \\
Sumatra & 36 \\
Sulawesi & 32 \\
Moluccas & 31 \\
Borneo & 29 \\
Philippines & 21 \\
China & 19 \\
Myanmar & 18 \\
Java \& Bali & 15 \\
Malayan Peninsula & 14 \\
Vietnam & 12 \\
Australia & 5 \\
India & 5 \\
Lesser Sunda & 0 \\
Thailand & 0 \\
Taiwan & 0
\end{tabular}

Table 8 Geographic origins of Rhododendron subg. Vireya (Argent 2015) ranked according to four 'not in cultivation' factors.

\begin{tabular}{|c|c|c|c|c|c|c|c|c|}
\hline \multirow[t]{2}{*}{ Ranking score } & \multicolumn{2}{|l|}{$\begin{array}{l}\text { No. of Red List taxa } \\
\text { 'not in cultivation' }\end{array}$} & \multicolumn{2}{|c|}{$\begin{array}{l}\text { Percentage of Red List taxa } \\
\text { 'not in cultivation' }\end{array}$} & \multicolumn{2}{|c|}{$\begin{array}{l}\text { No. Data Deficient taxa } \\
\text { 'not in cultivation' }\end{array}$} & \multicolumn{2}{|c|}{$\begin{array}{l}\text { Percentage of Data Deficient } \\
\text { taxa 'not in cultivation' }\end{array}$} \\
\hline & Origin & No. & Origin & $\%$ & Origin & No. & Origin & $\%$ \\
\hline 10 & New Guinea & 67 & $\begin{array}{l}\text { Sumatra } \\
\text { Moluccas }\end{array}$ & 80 & New Guinea & 49 & Sumatra & 90 \\
\hline 9 & $\begin{array}{l}\text { Borneo } \\
\text { Sulawesi }\end{array}$ & 13 & New Guinea & 74 & Sulawesi & 11 & Moluccas & 80 \\
\hline 8 & Sumatra & 12 & Malayan Peninsula & 67 & Sumatra & 10 & $\begin{array}{l}\text { New Guinea } \\
\text { Borneo }\end{array}$ & 78 \\
\hline 7 & $\begin{array}{l}\text { Philippines } \\
\text { Moluccas }\end{array}$ & 04 & Sulawesi & 65 & Borneo & 07 & Sulawesi & 75 \\
\hline 6 & $\begin{array}{l}\text { China } \\
\text { Malayan Peninsula }\end{array}$ & 02 & Myanmar & 50 & Philippines & 04 & Philippines & 67 \\
\hline 5 & $\begin{array}{l}\text { Java \& Bali } \\
\text { Myanmar }\end{array}$ & 01 & Borneo & 39 & Moluccas & 04 & China & 50 \\
\hline 4 & $\begin{array}{l}\text { Australia } \\
\text { India } \\
\text { Vietnam }\end{array}$ & 0 & China & 29 & China & 02 & $\begin{array}{l}\text { Java \& Bali } \\
\text { Myanmar } \\
\text { Vietnam }\end{array}$ & 0 \\
\hline 3 & & & Java \& Bali & 25 & $\begin{array}{l}\text { Vietnam } \\
\text { Myanmar } \\
\text { Java \& Bali }\end{array}$ & 0 & & \\
\hline 2 & & & Philippines & 21 & & & & \\
\hline 1 & & & $\begin{array}{l}\text { Australia } \\
\text { India } \\
\text { Vietnam }\end{array}$ & 0 & & & & \\
\hline 0 : nil taxa for the factor & $\begin{array}{l}\text { Lesser Sunda } \\
\text { Thailand } \\
\text { Taiwan }\end{array}$ & & $\begin{array}{l}\text { Lesser Sunda } \\
\text { Thailand } \\
\text { Taiwan }\end{array}$ & & $\begin{array}{l}\text { Australia } \\
\text { India } \\
\text { Lesser Sunda } \\
\text { Malayan Peninsula } \\
\text { Thailand } \\
\text { Taiwan }\end{array}$ & & $\begin{array}{l}\text { Australia } \\
\text { India } \\
\text { Lesser Sunda } \\
\text { Malayan Peninsula } \\
\text { Thailand } \\
\text { Taiwan }\end{array}$ & \\
\hline
\end{tabular}


Table 10 Taxonomic sections of Rhododendron subg. Vireya (Argent 2015) ranked according to four 'not in cultivation' factors.

\begin{tabular}{|c|c|c|c|c|c|c|c|c|}
\hline \multirow[t]{2}{*}{ Ranking score } & \multicolumn{2}{|l|}{$\begin{array}{l}\text { No. of Red List taxa } \\
\text { 'not in cultivation' }\end{array}$} & \multicolumn{2}{|l|}{$\begin{array}{l}\text { Percentage of Red List taxa } \\
\text { 'not in cultivation' }\end{array}$} & \multicolumn{2}{|l|}{$\begin{array}{l}\text { No. Data Deficient taxa } \\
\text { 'not in cultivation' }\end{array}$} & \multicolumn{2}{|l|}{$\begin{array}{l}\text { Percentage of Data Deficient } \\
\text { taxa 'not in cultivation' }\end{array}$} \\
\hline & Section & No. & Section & $\%$ & Section & No. & Section & $\%$ \\
\hline 10 & Schistanthe: euvireya & 30 & Siphonovireya & 86 & Schistanthe: euvireya & 24 & $\begin{array}{l}\text { Albovireya } \\
\text { Discovireya } \\
\text { Siphonovireya }\end{array}$ & $\begin{array}{l}100 \\
100 \\
100\end{array}$ \\
\hline 9 & Hadranthe & 23 & Hadranthe & 82 & Schistanthe: malesia & 18 & Schistanthe: malesia & 90 \\
\hline 8 & Schistanthe: malesia & 22 & Discovireya & 71 & Hadranthe & 14 & Schistanthe: solenovireya & 79 \\
\hline 7 & Schistanthe: solenovireya & 13 & Albovireya & 67 & Schistanthe: solenovireya & 11 & Hadranthe & 78 \\
\hline 6 & Discovireya & 10 & Schistanthe: malesia & 65 & $\begin{array}{l}\text { Albovireya } \\
\text { Siphonovireya }\end{array}$ & $\begin{array}{l}05 \\
05\end{array}$ & $\begin{array}{l}\text { Malayovireya } \\
\text { Schistanthe: linnaeopsis } \\
\text { Schistanthe: euvireya }\end{array}$ & $\begin{array}{l}67 \\
67 \\
67\end{array}$ \\
\hline 5 & $\begin{array}{l}\text { Albovireya } \\
\text { Siphonovireya }\end{array}$ & $\begin{array}{l}06 \\
06\end{array}$ & Schistanthe: linnaeopsis & 60 & Discovireya & 04 & Pseudovireya & 40 \\
\hline 4 & $\begin{array}{l}\text { Pseudovireya } \\
\text { Malayovireya }\end{array}$ & $\begin{array}{l}04 \\
04\end{array}$ & Schistanthe: solenovireya & 54 & $\begin{array}{l}\text { Pseudovireya } \\
\text { Malayovireya } \\
\text { Schistanthe: linnaeopsis }\end{array}$ & $\begin{array}{l}02 \\
02 \\
02\end{array}$ & & \\
\hline 3 & Schistanthe: linnaeopsis & 03 & Schistanthe: euvireya & 51 & & & & \\
\hline 2 & & & Pseudovireya & 40 & & & & \\
\hline 1 & & & Malayovireya & 36 & & & & \\
\hline $\begin{array}{l}\text { 0: nil taxa for the } \\
\text { factor }\end{array}$ & Schistanthe: saxifragoides & & Schistanthe: saxifragoides & & Schistanthe: saxifragoides & & Schistanthe: saxifragoides & \\
\hline
\end{tabular}

Table 11 Taxonomic sections of Rhododendron subg. Vireya (Argent 2015) ranked according to 'not in cultivation' score.

\begin{tabular}{ll}
\hline Taxonomic section & $\begin{array}{l}\text { 'Not in cultivation' score = sum of ranking scores } \\
\text { for four ‘not in cultivation' factors (Table 10). Maxi- } \\
\text { mum score = 40 }\end{array}$ \\
\hline Hadranthe (Phaeovireya) & 33 \\
Schistanthe: malesia & 32 \\
Siphonovireya & 31 \\
Schistanthe: euvireya & 29 \\
Discovireya & 29 \\
Albovireya & 28 \\
Schistanthe: solenovireya & 26 \\
Schistanthe: linnaeopsis & 18 \\
Pseudovireya & 15 \\
Malayovireya & 15 \\
Schistanthe: saxifragoides & 0 \\
\hline
\end{tabular}

\section{'Not in cultivation' analysis for subg. Vireya}

The utility of the 'not in cultivation' analysis is illustrated by New Guinea, which is the origin of the greatest number of Red List taxa in cultivation, suggesting that it is well placed for ex situ conservation; however, New Guinea is also the origin of the greatest number of Red List taxa 'not in cultivation', indicating that it actually has a high priority for ex situ action. When geographic origins are examined for four 'not in cultivation' factors (Table 8), New Guinea, Borneo, and Sulawesi have the greatest number of Red List taxa 'not in cultivation', while New Guinea and Sulawesi have the greatest number of Data Deficient taxa 'not in cultivation'. By percentage, Sumatra and the Moluccas have the highest percentage of Red List taxa 'not in cultivation', and Sumatra and the Moluccas the highest percentages of Data Deficient taxa 'not in cultivation'. When the ranking scores for each origin, for the four factors, are summed, a 'not in cultivation' score is generated (e.g. the score for New Guinea is $10+9+10+8=37$ ), showing that New Guinea and Sumatra have the highest scores, followed by Sulawesi and the Moluccas (Table 9).

When the same four 'not in cultivation' factors are applied to the taxonomic sections (Table 10), Schistanthe: euvireya has the greatest number of Red List taxa and Data Deficient taxa 'not in cultivation'. Siphonovireya and Hadranthe have the highest percentages of Red List taxa 'not in cultivation'. Three sections have $100 \%$ of their Data Deficient taxa 'not in cultivation' (Al-
Table 12 Geographic origins of Rhododendron subg. Vireya (Argent 2015) ranked according to Total score $=$ Red List score (Table 3) + 'not in cultivation' score (Table 9).

\begin{tabular}{lc}
\hline Origin & $\begin{array}{c}\text { Total score } \\
\text { Maximum score }=84\end{array}$ \\
New Guinea & 72 \\
Sumatra & 69 \\
Sulawesi & 65 \\
Moluccas & 55 \\
Borneo & 53 \\
Philippines & 50 \\
China & 48 \\
Myanmar & 40 \\
Java \& Bali & 28 \\
Vietnam & 27 \\
Malayan Peninsula & 18 \\
Australia & 11 \\
India & 11 \\
Lesser Sunda & 0 \\
Thailand & 0 \\
Taiwan & 0 \\
\hline
\end{tabular}

bovireya, Discovireya, Siphonovireya). The sections with the highest 'not in cultivation' scores are Hadranthe, Schistanthe: malesia and Siphonovireya (Table 11), which therefore have the poorest representation in cultivation.

\section{Ranking by Total Score}

Total Score, which prioritises groups for ex situ conservation, shows that geographic origins New Guinea, Sumatra, and Sulawesi should be assigned highest priority (Table 12). These three origins are in the top three ranks for both component scores, and while New Guinea has more taxa than the other two origins, Sumatra and Sulawesi have high percentages of taxa in the factors that generate the component scores. Because these three origins are in the top ranks for both component scores, they take top priority for both in situ and ex situ conservation. In contrast, although the Philippines has a relatively high Red List score, its taxa are relatively well represented in cultivation, so it ranks sixth for Total Score and has a lower priority for ex situ conservation. Vietnam is similarly placed: good representation in cultivation reduces its ranking in Total Score compared with its Red List score. The origins with the lowest priority for ex situ conservation according to Total Score are India, Australia, 
Table 13 Taxonomic sections of Rhododendron subg. Vireya (Argent 2015) ranked according to Total Score $=$ Red List score (Table 5) + 'not in cultivation' score (Table 11).

\begin{tabular}{lc}
\hline Taxonomic section & $\begin{array}{c}\text { Total score } \\
\text { Maximum score }=80\end{array}$ \\
\hline Schistanthe: malesia & 65 \\
Hadranthe (Phaeovireya) & 65 \\
Schistanthe: euvireya & 62 \\
Siphonovireya & 54 \\
Schistanthe: solenovireya & 51 \\
Albovireya & 49 \\
Discovireya & 46 \\
Pseudovireya & 38 \\
Schistanthe: linnaeopsis & 33 \\
Malayovireya & 31 \\
Schistanthe: saxifragoides & 0 \\
\hline
\end{tabular}

and Malayan Peninsula, although only five taxa in total come from these origins.

For taxonomic sections, Total Score shows that Schistanthe: malesia and Hadranthe (Phaeovireya) are equal first ranked (and take the top two ranks in both component scores), followed by Schistanthe: euvireya (Table 13). Of the other taxonomic sections, Discovireya is as poorly represented in cultivation as Schistanthe: euvireya, but it has a much lower Red List score, and is only mid-ranked for Total Score. Siphonovireya has a lesser conservation issue than Schistanthe: solenovireya, but ranks more highly in Total Score because of poorer representation in cultivation. Using the Total Score method, the taxonomic sections with the lowest priority for ex situ conservation are Malayovireya and Schistanthe: linnaeopsis.

\section{Vireya collections}

Of the 245 vireya taxa in cultivation, the largest collection is held at Royal Botanic Garden, Edinburgh (222 taxa), followed by New Zealand (151 taxa) and Dublin Botanic Garden (81). Edinburgh also holds the largest collection of Red List taxa, with 66 of the 80 taxa that are in cultivation, while New Zealand holds 33 Red List taxa and Dublin has 12. Royal Botanic Gardens, Kew holds only eight vireya taxa, including two Red List taxa, and is not a significant collection. There are 23 taxa in cultivation that are not held at Edinburgh; seven are in New Zealand and 22 are recorded at $\mathrm{BGCl}$. Wild-source material is present for 218 of the 245 taxa in cultivation (89\%), including 67 of the 80 Red List taxa (84 \%). Further analysis is needed to examine the taxonomic, geographic, and wild-source characteristics of these collections.

\section{Additional taxa}

The present study has recorded more taxa than the 400 considered in the Red List assessments (Gibbs et al. 2011, Argent 2015). Argent (2015) describes, but does not assess, four taxa of which one is in cultivation ( $R$. rugosum var. laeve, Borneo) and three are not in cultivation ( $R$. atrichum ssp. dendrolepis, Borneo; R. gaultherifolium ssp. expositum, New Guinea; R. suaveolens forma roseum, Borneo). He also describes 15 named natural hybrids of which seven are from Borneo, three from New Guinea, and five from other locations. Eleven of the hybrids are in cultivation, and nine have wild-source accessions. Also recorded in cultivation were another 40 wild-collected taxa, comprising 26 hybrids, six 'aff.' taxa and eight forms of species that are named as cultivars. Most of these taxa came from New Guinea (26), with seven from Borneo, and the remainder from other locations. None of the additional taxa was considered in the Red List assessments, so they were noted but not included in this analysis. Any that are deemed valid taxa will be placed in an appropriate position in a future Red List revision.

\section{Limitations to this study}

Several potential limitations to this study should be noted. Any analysis of a Red List assumes a robust Red List process in the first instance, and while the IUCN assessment categories require data on habitat, extent, threats and current degree of protection (Gibbs et al. 2011), some weaknesses of the 2011 assessment have been noted (MacKay 2013a, Ma et al. 2014). The difficulty of assembling the knowledge in one place at one time has been recognised (Oldfield 2010, Cires et al. 2013), and several iterations of a Red List assessment may be needed.

A second potential limitation is the range of data used to define taxa as 'in cultivation'. We used the online BGCl database (which contains 1359957 records of 498053 taxa at 1146 sites, bgic.org acc. 18 Aug. 2016) as a measure of taxa in cultivation in general, and the BGCl (2012) study to focus the comparison on the largest collections identified by that survey. Although the $\mathrm{BGCl}$ (2012) survey covered 304 botanic gardens world-wide, it did not cover every international collection, and it was not strongly representative of the countries of origin for vireya as it included only two sites in Southeast Asia (and seven in Australia). Further research should target additional vireya collections that may be relevant to a conservation programme.

The third possible limitation relates to the taxonomic analysis, which compared sections of different sizes, and highlights the tension between conservation of species diversity (e.g. the broad range of taxa in Schistanthe: euvireya) vs less common characters (e.g. the few taxa in Siphonovireya) (Paton 2009, Kozlowski et al. 2012, Castañeda-Álvarez et al. 2015). Such comparison hinges on the robustness of the sections, whereby small groups that are distinct could merit a high priority for conservation. Although recent molecular research largely supports most of the current taxonomic groupings (even though views differ on their ranking (Craven et al. 2008, 2011, Goetsch et al. 2011)), additional molecular research is needed to clarify these issues further.

Two further aspects should be noted. Firstly, as the New Zealand data were acquired over a range of time, it is possible that some accessions are no longer extant. Conversely, there may be further accessions in other collections that are yet to be discovered. Secondly, although some herbarium specimens have been assembled from the two largest New Zealand collections and identified by the authors, accessions in other New Zealand collections reported here have not been verified by any of the authors.

\section{CONCLUSIONS}

Analysis of the Red List for Rhododendron subg. Vireya shows that the highest priority for ex situ conservation should be assigned to New Guinea, Sumatra, and Sulawesi, and the taxonomic sections Schistanthe: malesia, Hadranthe (Phaeovireya), and Schistanthe: euvireya. Although two other origins (Borneo, the Philippines) have reasonably high numbers of Red List taxa, they are better represented in cultivation and have fewer Data Deficient taxa, and hence have a lower priority for ex situ conservation. One section, Pseudovireya, has a high percentage Red Listed; however, Data Deficiency is low and percentage in cultivation is high, so this section also has a lower priority for ex situ conservation.

Of the 400 vireya taxa, 245 are in cultivation, with the largest collection at Edinburgh which holds $91 \%$ of the taxa in cultivation. The collections investigated have several strengths (a substantial range of taxa and Red List taxa, wild-source accessions, and reasonable representation of some geographic origins); however, they also have weaknesses. These include poor representation of some priority geographic and taxonomic 
groups, and poor security in cultivation, as shown by an almost universally low average number of records on the $\mathrm{BGCl}$ database. Our analysis shows that there is considerable work needed to achieve Target 8 of the Global Strategy for Rhododendron subg. Vireya and our research provides a sound basis for further development. We propose six priorities and actions for conservation:

1. Taxa from New Guinea, Sumatra, and Sulawesi, and the taxonomic sections Schistanthe: malesia, Hadranthe, and Schistanthe: euvireya should have highest priority for ex situ conservation. Increasing the number of accessions in cultivation is a key task; activities should include propagation and dispersal of existing accessions, as well as acquisition of new accessions.

2. Mitigation of the risk of the limited number of collections should be addressed. The need for an international network of collections was identified at the Species Conservation Workshop of 2013 (MacKay 2013a) and a group should be formed to advance this initiative for subg. Vireya. Decisions are needed on the number and location of sites required world-wide, including collections in countries of origin, as well as the range of taxa to be held at each site.

3. As New Zealand collections appear to be significant worldwide, the potential role of New Zealand collections for ex situ conservation should be further investigated.

4. The true threat status of the 113 Data Deficient taxa should be investigated. Only 26 are in cultivation and bringing the remainder into cultivation is desirable, as are the field work and research needed to clarify their Red List assessment.

5. Because our Red List assessment also informs in situ conservation, an investigation should be undertaken into current in situ programmes for New Guinea, Sumatra, and Sulawesi (involving the countries of Indonesia, Malaysia, and Papua New Guinea). The taxonomic sections Schistanthe: malesia, Schistanthe: euvireya and Hadranthe attained the highest Red List scores in our analysis, suggesting a high priority for in situ conservation; however, the sections vary in their geographic characteristics. Hadranthe are almost all from New Guinea and so any in situ programme there would be likely to capture those taxa. The other two sections are spread across several islands and countries, making an in situ investigation somewhat harder to focus.

6. A policy framework for a global ex situ conservation plan for Rhododendron subg. Vireya must be developed to support the previous recommendations. Decisions are needed on the balance between acquiring more accessions of taxa already in cultivation and searching out taxa that are not in cultivation. A process to investigate Data Deficient taxa should be identified and an international procedure for propagation and distribution established. These activities should take place within international regulations such as the Nagoya Protocol, or New Zealands strict plant import regulations. The role of some countries may be limited to certain aspects, e.g. New Zealand could export accessions to other collections; however, cannot easily import additional taxa.

Rhododendron subg. Vireya is a large plant group with taxa from a wide range of habitats and niches in Southeast Asia, and as such provides an instructive example for conservation planning. Management of conservation of one of the larger genera of flora of Southeast Asia will advance the whole conservation cause in this region. Our method has combined an analysis of the Red List with an analysis of the incidence of taxa in cultivation, to identify geographic origins and taxonomic sections that should have priority for ex situ conservation, and to focus conservation effort on the most urgent groups of taxa within the subgenus.
We have proposed six conservation priorities and actions. Any ex situ conservation plan should be embedded into an overall (in situ and ex situ) conservation strategy, yet to be formulated, with this analysis providing a useful component for development of that strategy.

Acknowledgements This study has sourced data from several online databases and we appreciate the opportunity to access those databases. We also thank collection owners in New Zealand who contributed data to this study. We are very grateful to the New Zealand Rhododendron Association, Pukeiti Rhododendron Trust and Taranaki Regional Council, The New Zealand Institute for Plant \& Food Research Limited, and Massey University for supporting this research.

\section{REFERENCES}

Argent G. 2015. Rhododendron of the subgenus Vireya. 2nd ed. Royal Botanic Garden, Edinburgh, in association with The Royal Horticultural Society, UK.

Arnet M, Santos B, Brockerhoff E, et al. 2015. Importance of arboreta for ex situ conservation of threatened trees. Biodiversity Conservation 24: 3601-3620.

Beech E, Shaw K, Jones M. 2015. Global survey of ex situ Betulaceae collections. Botanic Gardens Conservation International, Richmond, UK. Downloaded from bgci.org on 3 May 2016.

BGCl. 2012. Global survey of ex situ Rhododendron collections. Botanic Gardens Conservation International, Richmond, UK. Downloaded from bgci.org on 2 Dec. 2015.

Blackmore S, Gibby M, Rae D. 2011. Strengthening the scientific contribution of botanic gardens to the second phase of the Global Strategy for Plant Conservation. Botanical Journal of the Linnaean Society 166: 267-281.

Brockerhoff E, Given D, Ecroyd C, et al. 2004. Biodiversity: conserving threatened introduced species. Final report for MAF operational research 2003 - 4. Centre for Sustainable Management and Forest Research, Ministry of Agriculture and Forestry, New Zealand.

Brown GK, Craven LA, Udovicic F, et al. 2006a. Phylogeny of Rhododendron section Vireya (Ericaceae) based on two non-coding regions of cpDNA. Plant Systematics and Evolution 257: 57-93.

Brown GK, Nelson G. Ladiges PY. 2006b. Historical biogeography of Rhododendron section Vireya and the Malesian archipelago. Journal of Biogeography 33: 1929-1944.

Castañeda-Álvarez NP, De Haan S, Juárez H, et al. 2015. Ex situ conservation priorities for the wild relatives of potato (Solanum L., section Petota). PLoS ONE 10, 4: e0122599. doi:10.1371/journal.pone.0122599.

Cavender N, Westwood M, Bechtoldt C, et al. 2015. Strengthening the conservation value of ex situ tree collections. Oryx 49, 3: 416-424.

Chamberlain D, Hyam R, Argent G, et al. 1996. The genus Rhododendron: its classification and synonymy. Royal Botanic Garden, Edinburgh, UK.

Christe C, Kozlowski G, Fry D, et al. 2014. Do living collections capture the genetic variation of wild populations? A molecular analysis of two relict tree species, Zelkova abelica and Zelkova carpinifolia. Biodiversity Conservation 23: 2945-2959.

Cires E, De Smet Y, Cuesta C, et al. 2013. Gap analysis to support ex situ conservation of genetic diversity in Magnolia, a flagship group. Biodiversity Conservation 22: 567-590.

Craven LA, Danet F, Veldkamp JF, et al. 2011. Vireya Rhododendrons: their monophyly and classification (Ericaceae, Rhododendron section Schistanthe). Blumea 56: 153-158.

Craven LA, Goetsch LA, Hall BD, et al. 2008. Classification of the Vireya group of Rhododendron (Ericaceae). Blumea 53: 435-442.

Crutwell NEG. 1988. Natural hybridization among Rhododendrons in Papua New Guinea. The Rhododendron (Australia) Vol.27, 3, March 1988.

Cullen M. 2005. Hardy rhododendron species: a guide to identification. Royal Botanic Garden, Edinburgh, UK.

Dawson M (ed). 2010. Documenting New Zealand's cultivated flora: A supermarket with no stock inventory. Landcare Research, Lincoln, New Zealand.

Ennos RA, French GC, Hollingsworth PM. 2005. Conserving taxonomic complexity. Trends in Ecology and Evolution 20, 4: 164-168.

Farnsworth EJ, Klionsky S, Brumback WE, et al. 2006. A simple set of decision matrices for prioritising collection of rare plant species for ex situ conservation. Biological Conservation 28: 1-12.

Fayaz A. 2012. Biodiversity of Rhododendron in New Zealand and its potential contribution to ex-situ conservation. Unpubl. PhD thesis, Massey University, New Zealand.

Frodin DG. 2004. History and concepts of big plant genera. Taxon 53, 3: $753-776$. 
Gibbs D, Chamberlain D, Argent G. 2011. The Red List of Rhododendrons. Botanic Gardens Conservation International, Richmond, UK.

Gibbs D, Chen Y. 2009. The Red List of Maples. Botanic Gardens Conservation International, Richmond, UK. Downloaded from bgci.org on 3 Mar. 2016.

Given DR. 1987. What the conservationist requires of ex situ collections. In: Bramwell D, Hamann O, Heywood VH, et al. (eds), Botanic gardens and the world conservation strategy: proceedings of an international conference, 26-30 November 1985 held at Las Palmas de Gran Canaria: 103-116. IUCN \& Academic Press, London.

Goetsch LA, Craven LA, Hall BD. 2011. Major speciation accompanied the dispersal of Vireya Rhododendrons (Ericaceae, Rhododendron sect. Schistanthe) through the Malayan archipelago: Evidence from nuclear gene sequences. Taxon 60, 4: 1015-1028.

Goodall-Copestake WP, Hollingsworth ML, Hollingsworth PM, et al. 2005. Molecular markers and ex situ conservation of the European elms (Ulmus ssp.). Biological Conservation 122: 537-546.

Heywood VE, Iriondo JM. 2003. Plant conservation: old problems, new perspectives. Biological Conservation 113: 321-335.

IUCN. 2011. The global strategy for plant conservation 2011-2020. IUCN Plant Conservation Committee Fact Sheet February 2011

Kozlowski G, Gibbs D, Huan F, et al. 2012. Conservation of threatened relict trees through living ex situ collections: lessons from the global survey of the genus Zelkova (Ulmaceae). Biodiversity Conservation 21: 671-685.

Lasco RD, Uebelhör K, Follisco Jr F. 2010. Facing the challenge of biodiversity conservation and climate change in Southeast Asia. Climate and Development 2, 3: 291-294.

Leadlay E, Willison J, Wyse-Jackson P. 2006. Taxonomy: the framework for botanic gardens in conservation. In: Leadlay E, Jury S (eds), Taxonomy and Plant Conservation: 274-293. Cambridge University Press, UK.

Leslie AC. 2004. The international Rhododendron register and checklist. 2nd ed. Royal Horticultural Society, UK.

Lowe RAW. 1988. The National Council for the Conservation of Plants and Gardens (NCCPG). Royal New Zealand Institute of Horticulture Annual Journal 15: 29-31.

Lowe T. 1989. The way ahead. The Garden 114: 364-368.

Ma Y, Nielsen J, Chamberlain DF, et al. 2014. The conservation of Rhododendrons is of greater urgency than has been previously acknowledged in China. Biodiversity Conservation 23: 3149-3154.

MacKay MB. 1995. A survey of exotic tree collections in New Zealand. Horticulture in New Zealand 6, 1: 42-46.

MacKay MB. 2005. The value of ex situ woody plant collections in New Zealand: management and conservation issues. Oral presentation at 'Saving Threatened Tree Species - International Progress in Tree Conservation' on 8 Sept. 2005, at Cambridge University Botanic Garden, UK.

MacKay MB. 2013a. Report on the Rhododendron Species Conservation Conference: April 21-22, Edinburgh. The Rhododendron (New Zealand) 1: 6-9.

MacKay MB. 2013b. Data management for ex situ conservation planning: the example of Rhododendron. Oral presentation to the 5th Global Botanic Gardens Congress, Dunedin, Oct. 2013.

MacKay MB, Gardiner SE. Unpublished. A model for determining ex situ conservation priorities in 'big genera' is provided by analysis of the subgenera of Rhododendron L. (Ericaceae). Paper submitted to Biodiversity Conservation 22.4.16.

Maunder M, Byers O. 2005. The IUCN technical guidelines on the management of ex situ populations for conservation: reflecting major changes in the application of ex situ conservation. Oryx 39, 1: 95-98.
Maunder M, Culham A, Alden B, et al. 2000. Conservation of the Toromiro tree: case study in the management of a plant extinct in the wild. Conservation Biology 14, 5: 1341-1350.

Maunder M, Higgins S, Culham A. 2001a. The effectiveness of botanic garden collections in supporting plant conservation: a European case study. Biodiversity Conservation 10: 383-401.

Maunder M, Lyte B, Dransfield J, et al. 2001b. The conservation value of botanic garden palm collections. Biological Conservation 98: 259-271.

Milne RI, Davies C, Prickett R, et al. 2010. Phylogeny of Rhododendron subgenus Hymenanthes based on chloroplast DNA markers: betweenlineage hybridisation during radiation? Plant Systematics and Evolution 285: 233-244.

Newton A, Oldfield S. 2008. Red Listing the world's tree species: a review of recent progress. Endangered Species Research 6: 137-147.

Oldfield S. 2009. Botanic gardens and the conservation of tree species. Trends in Plant Science 14, 11: 581-583.

Oldfield S. 2010. Plant conservation: facing tough choices. BioScience 60, 10: $778-779$.

Oldfield S, Eastwood A. 2007. The Red List of oaks. Flora and Fauna International, Cambridge, UK. Downloaded from bgci.org on 3 May 2016.

Paton A. 2009. Biodiversity informatics and the plant conservation base line. Trends in Plant Science 14, 11: 629-637.

Powledge F. 2011. The evolving role of botanical gardens. BioScience 61, 10: 743-749.

Pritchard DJ, Fa JE, Oldfield S, et al. 2011. Bring the captive closer to the wild: redefining the role of ex situ conservation. Oryx 46, 1: 18-23.

Rae D. 2011. Fit for purpose: the importance of quality standards in the cultivation and use of live plant collections for conservation. Biodiversity Conservation 20: 241-258.

Rivers M, Beech E, Murphy L, et al. 2016. The Red List of Magnoliaceae - revised and extended. Botanic Gardens Conservation International, Richmond, UK.

Rouse JL, Knox RB, Williams EG. 1993. Inter- and intraspecific pollinations involving rhododendron species. Journal of the American Rhododendron Society $47,1$.

Sharrock S. 2012. Global Strategy for Plant Conservation. A guide to the GSPC: all the targets, objectives and facts. Botanic Gardens Conservation International, Richmond, UK.

Shaw K, Stritch L, Rivers M, et al. 2014. The Red List of Betulaceae. Botanic Gardens Conservation International, Richmond, UK.

Van Welzen PC, Slik JWF, Alahuhuta J. 2005. Plant distribution patterns and plate tectonics in Malesia. In: Friis I, Balslev $\mathrm{H}$ (eds), Plant diversity and complexity patterns: local, regional and global dimensions. Proceedings of an international symposium held at the Royal Danish Academy of Sciences and Letters, Copenhagen 25-28 May 2003: 199-217. Danske Videnskabernes Selskab.

Webb CO, Ree R. 2012. Historical biogeography inference in Malesia. In: Gower D (ed), Biotic evolution and environmental change in Southeast Asia: 181-215. Cambridge University Press, UK.

Williams EG, Rouse JL, Palser BF, et al. 1990. Reproductive biology of Rhododendron. Horticultural Reviews 12: 1-68.

Williams S, Jones JPG, Clubbe C, et al. 2012. Why are some biodiversity policies implemented and others ignored? Lessons from the uptake of the Global Strategy for Plant Conservation by botanic gardens. Biodiversity Conservation 21: 175-187.

Wyse-Jackson P, Kennedy K. 2009. The Global Strategy for Plant Conservation: a challenge and opportunity for the international community. Trends in Plant Science 14, 11: 578-580. 